\title{
A digital Jewish history?
}

\author{
Dr. Carmen Smiatacz
}

Institute for the History of the German Jews, Hamburg, Germany, geschichtomat@igdj-hh.de

\begin{abstract}
How can we teach Jewish history in a modern and effective way? In Hamburg, Germany, a school project called Geschichtomat tries to find an answer to that question. With the help of digital media, students explore their Jewish neighbourhood. This one-of-a-kind German program permits students to experience the Jewish past and present life in their hometown. During the project, students explore their neighbourhood to understand its historical figures, places, and events. This way they engage with Jewish life. Under the supervision of experts in the disciplines of history and media education, the students will: research, perform interviews with cultural authorities and contemporary witnesses, visit museums and archives, shoot and cut films, edit photos and write accompanying texts. Finally, their contributions are uploaded to the geschichtomat.de website. Little by little a digital map of Jewish life from the perspective of teenagers will take shape.
\end{abstract}

Keywords: history; media education; project work

\section{Introduction}

In Hamburg, Germany, students explore their Jewish neighbourhood with the help of a project called Geschichtomat (transl. history machine). The project gives an idea of how to teach all areas of history, but especially Jewish history, in a modern, interesting and effective way. In 2010, before initialising Geschichtomat, researchers from the Institute of the History of the German Jews took a look at the range of events offered to schools and students to experience and explore Jewish history in Hamburg. More than 100 events, for example, guided tours, memorial sides, biographical research, were found. Almost all of them dealt with the topics of persecution, extermination and death.

The same results can be found looking at German school classes. The problem of history classes is that, at least in Germany, Jewish history and culture is almost always taught from the perspective of victims. An empiric study of German schoolbooks shows that Jewish history is mainly connected to the topics of National Socialism and the Holocaust (Liepach \& Geiger, 2014, p. 15). This leaves us with two problems. Firstly, the two thousand year-long Jewish history of Europe seems to lead automatically to the Holocaust. Parallels are being drawn between the medieval persecutions and the Antisemitism of the 19th century, to National Socialism. Therefore, early Jewish history tends to be seen as just a pre-history of the Holocaust. A second problem arises of not teaching about periods when Jewish and non-Jewish people were living peacefully together. Jews appear as a perpetually-sidelined minority. (Liepach \& Geiger, 2014, pp. 176-177).

At the beginning of a Geschichtomat project week, the knowledge of the students about Jewish history and culture in Hamburg is tested. The students are supposed to write down in a mind-map what they already know and what comes to their mind when they think of Jewish history. Usually, the first association is National Socialism and the Holocaust. Keywords like Auschwitz and persecution are named. After a while, some students remember learning about Judaism in $5^{\text {th }}$ or $6^{\text {th }}$ grade in religious education. Almost no one can tell a name of a famous Hamburg Jew. If being told that the shipping agent Albert Ballin, the inventor of Nivea Creme Oskar Troplowitz and the family of the poet Heinrich Heine were Jewish, the students and teachers are surprised. This leads to the question: How can Jewish history be taught differently? How can students be interested in it and connect with it? Can school projects help and maybe digital media?

\section{What Is Geschichtomat?}


Geschichtomat is a weeklong student-driven project with the purpose of revealing Jewish history and culture in Hamburg. This one-of-a-kind German program allows students to experience the Jewish past- and present life in their hometown. During the project, students explore their neighbourhood to understand its historical figures, places, and events. This way they engage with Jewish life. Under the supervision of experts in the disciplines of history and media education, the students will: research, perform interviews with cultural authorities and contemporary witnesses, visit museums and archives, shoot and cut films, edit photos, and write accompanying texts. Finally, their contributions are uploaded to the geschichtomat.de website. Little by little, a digital map of Jewish life from the perspective of teenagers will take shape.

As the topics are located in the schools' neighbourhood, chosen freely by the students, and because the participants must develop their own questions, the students get the opportunity of an individual approach to history. Therefore, ritualized forms of remembrance are ended.

Geschichtomat is a part of the Institute of the History of the German Jews. After two years of development, the first project week began in February 2013 at a Catholic school. Since then, 23 different project weeks at 18 different schools have taken place. Over 500 students from $7^{\text {th }}$ to $12^{\text {th }}$ grade participated so far: they visited Jewish cemeteries, tasted kosher gummi bears, researched biographies, visited museums and memorial sides, baked matzo, interviewed a Rabbi and visited a synagogue. Over 100 short videos were created. The participation at Geschichtomat is free for schools. The teacher can contact the Geschichtomat office and register his/her class for it. The project manager advertises the project during workshops and conferences. Also, publicity materials such as flyers exist, which is send to schools, but also to other education facilities. More information can be found at the Geschichtomat website and on Facebook.

\section{How Does Geschichtomat Work?}

Before a project week starts there are two meetings between the project manager (the author of this article) and the teacher with their class. During those meetings, everyone gets to know each other; the students learn about Geschichtomat and what is going to happen during the project week. But the meeting is also a chance to discover what kind of knowledge the students already have. In Hamburg, the students explore the former Jewish part of the city as part of the second meeting. During a rally, they learn about former places of Jewish life and explore what remains. The results of the rally are being presented and discussed in class. At the end, the project manager presents different topics for the next week to the students. The students must form groups of four to five and choose their topic.

The project week is led by a team of two media educators and one cultural educator. The required technical equipment is also provided by the media educators. The school needs only a classroom, some computers for research and a teacher who supports the Geschichtomat team. Before the project week starts, the project manager has researched the topics, prepared material and fixed dates with possible interview partners. This must be done in advance; otherwise the time during one week would be too short.

The project week starts with the familiarization of the various topics. Reading material on their subject is distributed. The students also find out if they have an interview, when it is and with whom. These interviews need to be prepared, questions must be found and a setup needs to be arranged. The media educators also give the students a brief introduction to the technical equipment. For many students, it is the first contact with a professional camera; therefore, they must learn how to set it up and how to work with it.

The students also need to learn how to tell a story. At the same time, they explore their neighbourhood; therefore, they have a direct connection with what they are learning about. History must be made sense of with Geschichtomat because the students are required to tell their own story and shoot their own video. In order to do that, they need to cope with a lot of information, filter it and give it structure. By choosing what should and shouldn't be included in the video, students learn that history always has a narrator. Therefore, they always need to ask for the purpose for which the information was supplied (Barricelli, 2012, p. 261). At the same time, the students deal with the internet as a source of information; they learn to filter their findings and to evaluate them. (Bernsen, König \& Spahn, 2012, pp. 6-8).

On the second and third day, the material for the video is collected. Interviews are recorded, pictures taken and introductions written. Due to the different sources the students use - the interviews with experts and contemporary witnesses to pictures, files and texts - the students get to know a variety of views on history and the past (Bergmann, 2008, p. 160). With these different views, the students can discuss all kinds of perspectives and interpretations of history. Therefore, the idea of a linear history comes to an end (Bernsen, König \& Spahn, 2012, p. 8). Thanks to the interviews with experts and contemporary witnesses, the students are able to connect with people from different generations. Yet the students control the discussion and ask their own questions. Therefore, they are not only receivers but active players. This is normally different in school as well as other places of learning. There the teacher hosts, and controls, the discussion. (Kowitz-Harms \& Menny, 2014, p. 334).

Geschichtomat offers the opportunity to look into different cultures. An 'intercultural learning of history' takes shape (Jebrak, p. 8). Many students have a migration back-ground, particularly in larger cities and metropolis. Different religions and cultures can be found within one classroom. This gives the students the opportunity to have discussions about their own and also other, less familiar, identities.

Cutting the videos is the longest and hardest part of the project week. The students must focus on the task. They are required to listen to the interviews repeatedly, filter important information and understand the context. Generally, few students have experience with a professional editing program. Some have filmed with their smartphones; others have 
uploaded short videos to YouTube. Yet short documentaries are being made for Geschichtomat and they need to be correct in form and content. The standard is a different one than for the self-made smartphone videos.

That is why the students need to work with the internet. Their videos must be correct in form and content, yet they must also be interesting and visually appealing. To ensure the attention of future users, the videos should not be longer than four- to five minutes. They should capture the audience's attention, be diverse and offer a variety of media such as music and pictures. Having a script is therefore very important. (Kowitz-Harms \& Menny, 2014, p. 335) At the same time the students cannot get too excited over the technical elements - the content should not be lost. It is the responsibility of the teacher and the Geschichtomat team to ensure that the content is correct.

\section{Using Digital Media - Chances and Risks}

At the end of the project week, the videos are uploaded to the Geschichtomat website. The students also give a presentation in the classroom or for other classes. The publication of the videos in the internet gives them a higher value than simply showing them in front of other students. This can also lead to a reflection about the power of internet. On the one hand, the easily-accessible opportunity to publish their videos allows the students to become producers of history. It creates space for profiling and presentation. There are always risks associated with publishing in the internet, however. The spread of the videos is essentially beyond their control. Therefore, the Geschichtomat videos are not publically listed on YouTube; they can only be found on the Geschichtomat website.

During the project, the students are sensitized to using different sources and the presentation of certain subjects in the internet. They need to think about being seen on camera. This is also true for the interview partners. Personal rights, but also copy-rights of pictures and music, must remain protected. Therefore Geschichtomat videos can only include pictures, videos and sound for which the copyright is clear. Usually, the students have to produce all the material themselves. Nowadays, teenagers upload many different types of documents to social media websites such as Facebook or Instagram. Sensitizing them to copyrights and the use of media is a very important part of modern media education. Showing the results of a project week online gives the opportunity to reuse the material for education, thereby enabling individual and exploratory learning. Audiovisual media can be used successfully for history classes due to its connection to students' everyday lives. (Binnenkade, 2013, p. 346).

Different kinds of sheets for using the videos in class can be found on the Geschichtomat website. The subjects 'kosher food', 'Jewish cemeteries' and 'the transport of children to the UK during National Socialism' are featured. The sheets explain to the students which video they should watch. Afterwards, there are several questions to be answered and different work assignments are written down. The students need to understand but also to question the videos they have just seen. A new kind of debate about history arises from them. They are made by the students for students.

Over the past years, the project has been evaluated. About 400 students participated in this evaluation so far. Firstly, they were asked if they liked Geschichtomat. The majority did like it ( $27 \%$ very much, 56\% much), 13\% thought it was okay and $4 \%$ disliked the project. The second question asked if the students felt like they could decide for themselves what was in their video and work freely. Yet again, the majority agreed to that question (40\% very much, $41 \% \mathrm{much}$ ). $18 \%$ said not so much and $4 \%$ not at all. The last question dealt with what the students had learnt. The students should tell what they had never done before in school (more than one answer was possible). Out of 357 students, the majority (249 students) said 'learning about Jewish history and culture'. 85 students also replied that they had never worked with media. 15 students had never worked on a project and 8 never in a team.

\section{Conclusions}

Several museums, institutions and memorial sites all over Germany offer digital platforms to Jewish life, history and culture. ${ }^{1}$ Yet there is a lack of empirical research about digital historical learning (Kowitz-Harms, 2015, p. 10). Only few studies exist (e.g. Schwabe, 2012; Hodel 2013; Alavi \& Schäfer, 2010; Schmitt \& Kowski, 2011; John, 2013). The question is if and how the online platforms are being used by students and teachers. By knowing this, the digital educational offers can be created and developed (Schwabe, 2012, pp. 405). This becomes even more significant looking at the general Jewish history. So far no empirical study about digital learning in this field exists. Concerning the Holocaust, there are at least two different studies about the internet as a place of remembrance and the presentation and perception of the same. (Hein, 2009; Frieden, 2014).

The project Geschichtomat shows that, with the help of digital media, history can be taught in a modern way. The participating students explore and investigate their own neighbourhood. They learn about Jewish history in a novel, unique way. A link to Jewish culture, history and life can be established. In a normal school lesson this would not happen. Jewish people are no longer just victims; Jewish history is no longer just a history of persecution but forms part of the city' history. The use of digital media helps to make the project interesting for students and connect with their daily life. The internet is part of their everyday lives and is also becoming increasingly important in school. Therefore, a

\footnotetext{
${ }^{1}$ E.g. Lebendiges Museum Online (LeMO): https://www.dhm.de/lemo [23.05.2017], Foundation Memorial to the Murdered Jews of Europe: Sprechentrotzallem: http://www.sprechentrotzallem.de [23.05.2017], Jewish Museum Berlin: http://www.jmberlin.de/materialienfuer-schulen [23.05.2017], Fritz Bauer Institute, Before the Holocaust: http://www.vor-den-holocaust.de [23.05.2017].
} 
proper way of interacting with it must be taught. The students need to learn how to use the internet for research but they must also see the risks and problems presented by it (Kowitz-Harms \& Menny, 2014, p. 341).

Currently, Geschichtomat only exists in Hamburg, Germany. Last year, the technical requirements were enabled for an enlargement of the project. Theoretically, videos from all over the world can be uploaded to the website and be linked with a dot on the map.

\section{References}

Alavi, B. \& Schäfer, M. (2010). Historisches Lernen und Lernstrategien von Jugendlichen. Eine empirische Untersuchung zu historischer Selbstlernsoftware. In B. Alavi (Ed.), Historisches Lernen im virtuellen Medium. (pp. 75-93). Heidelberg: Mattes.

Barricelli, M. (2012). Narrativität. InM. Barricelli, \&M- Lücke (Eds.),Handbuch Praxis des Geschichtsunterrichts (pp. 255-280). Schwalbach/Ts: Wochenschau Verlag.

Bergmann, K.(2008). Geschichtsdidaktik. Beiträge zu einer Theorie historischen Lernens. Schwalbach/Ts: Wochenschau Verlag.

Bernsen, D., König, A., \&Spahn, Th.(2012). Medien und historisches Lernen: Eine Verhältnisbestimmung und ein Plädoyer für eine digitale Geschichtsdidaktik,Zeitschrift für digitale Geschichtswissenschaft, (1), 1-27.

Binnenkade, A. (2013). Audiovisuelle Medien. Ein interdisziplinärer Beitrag. InM. Furrer, \&K. Messmer (Eds.), Handbuch Zeitgeschichte im Geschichtsunterricht(pp. 338-351). Schwalbach/Ts: Wochenschau Verlag.

Frieden, K. (2014). Neuverhandlungen des Holocaust. Mediale Transformationen des Gedächtnisparadigmas. Bielefeld: transcript.

Hein, D. (2009). Erinnerungskulturen online. Angebote, Kommunikatoren und Nutzer von Websites zu Nationalsozialismus und Holocaust. Konstanz: UVK-Verlag.

Hodel, J. (2013). Verkürzen und verknüpfen. Geschichte als Netz narrativer Fragmente. Wie Jugendliche digitale Netzmedien für die Erstellung von Referaten im Unterricht verwenden. Bern: hep.

Jebrak, S.Angekommen?! Jüdische Zuwanderung nach Deutschland 1990-2010. Materialien und Vorschläge zur pädagogischen Arbeit. Jüdisches Museum Westfalen (Eds.).

John, A. (2013). Geschichtsdidaktik 2.0. Vom Nutzen und Nachteil internetbasierten Studierens im Lehramt Geschichte. In S. Popp (Ed.), Zur Professionalisierung von Geschichtslehrerinnen und Geschichtslehrern (pp. 279298). Göttingen: Vandenhoeck\&Ruprecht.

Kowitz-Harms, St., \& Menny, A. (2014). Schülerprojekt Geschichtomat. Zur Vermittlung jüdischer Geschichte im Internet,Demokratische Geschichte, (25), 329-342.

Kowitz-Harms, St. (2015), Online-Sein oder Nicht-Sein - das ist die Frage. Anregungen zur Reflexion über digitale Vermittlungsangebote zur jüdischen Geshcichte und Kultur, Medaon, (9) 17, 1-12, http://www.medaon.de/pdf/medaon 17 Kowitz-Harms.pdf [23.05.2017].

Liepach, M., \& Geiger, W.(2014ㄹ). Fragen an die jüdische Geschichte. Darstellungen und didaktische Herausforderungen. Schwalbach/Ts: Wochenschau Verlag.

Schmitt, Ch. \& Kowski, N. (2011). Zwischen Handbuch und „Facebook“. Was erwarten Studierende von einem geschichtlichen Fachportal? Online-Umfrage zu historicum.net Geschichtswissenschaften im Internet, Geschichte in Wissenschaft und Unterricht, (62), 655-668.

Schwabe, A. (2012). Historisches Lernen im World Wide Web. Suchen, flanieren oder forschen? Fachdidaktischmediale Konzeption, praktische Umsetzung und empirische Evaluation der regionalhistorischen Website Vimu.info. Göttingen: Vandenhoeck \& Ruprecht. 